abrade the tricuspid valve or right ventricular endothelium, and if infection arises the risk of right heart endocarditis must increase.

Many of these complications may be reduced. Puncture of the subclavian vein with the patient in the head down position reduces air embolism. Strict attention to aseptic technique and the availability of a parenteral nutrition team reduce infection as does subsequent careful handling of the catheter. ${ }^{27}$ Flushing antifungal agents through the catheters reduces infection. Some centres advocate low dose heparin, either subcutaneously or through the catheter, to prevent thrombosis. ${ }^{13}$

We have recently seen a patient with tricuspid endocarditis after central venous cannulation and a patient who died after pulmonary embolus from a sterile right ventricular thrombus. Both patients had a septicaemic illness. In the patient who died two dimensional echocardiography clearly showed the catheter prolapsing across the tricuspid valve during atrial systole. This emphasises that all right atrial catheters must be carefully positioned within the high right atrium (and confirmed by chest radiography) to avoid damage to the tricuspid valve. Furthermore, patients who develop a septicaemic illness should undergo two dimensional echocardiography even after withdrawal of the catheter to detect any potentially serious intracardiac thrombi or vegetations.

C G KAYE

Cardiac Registrar

D R SMITH

Consultant Cardiologist

General Infirmary,

Leeds LS1 3EX

1 Bernard RW, Stahl WM. Subclavian vein catheterisation: a prospective study. I. Non-infective complications. Ann Surg 1969;169:974-84.
Wilmore WD, Dudrick SJ. Safe long term venous catheterisation. Arch Surg 1969;98:256-8. 3 Herbst CA. Indications, management and complications of percutaneous subclavian catheters. Arch Surg 1978;113:1421-5.

4 Borja AR. Current status of infraclavicular subclavian vein catheterisation. Ann Thorac Surg 1972;13:615-24

5 Smith BE, Modell JH, Gaub ML, Moya F Complications of subclavian vein catheterisation. Arch Surg 1965;90:228-9.

6 Lange HW, Galliani CA, Edwards JE. Local complications associated with indwelling Swan-Ganz catheters. Autopsy study of 36 patients. Am $\mathcal{F}$ Cardiol 1983;52:1108-11

7 Chute E, Cerra F. Late development of hydrothorax and hydromediastinum in patients with central venous catheters. Crit Care Med 1982;10:868-9.

8 Flanagan JP, Gradisar IV, Gross RJ, Kelly TR. Air embolus: a lethal complication of subclavian venepuncture. N Engl f Med 1969;281:488-9.

9 Ryan JA Jr, Abel RM, Abbott WM, et al. Catheter complications of total parenteral nutrition. NEngl f Med 1974;290:757-61.

10 Bozzetti F. Central venous catheter sepsis: the experience of the Instituto Nazionale Tumori of Milan. Acta Anaesthesiol Scand [Suppl] 1985;81:53-7.

11 Curry CR, Quie PG. Fungal septicaemia in patients receiving parenteral hyperalimentation NEngl F Med 1971;285:1221-5.

12 Brennan MF, Goldman MH, O'Connell RC, Kundsin RB, Moore FD. Prolonged parenteral alimentation: candida growth and prevention of candidemia by amphotericin instillation. Ann Surg 1972;176:265-72.

13 De Jong PCM, Von Meyenfeldt R, Rouflart M, Wesdorp RIC, Soeters PB. Complications of central venous catheterization of the subclavian vein. Acta Anaesthesiol Scand [Suppl] 1985;81:48-52. 4 Garden OJ, Sim AJW. A comparison of tunnelled and untunnelled subclavian catheters: a prospective study of complications during parenteral feeding. Clinical Nutrition 1983;2:51-4.

15 Von Meyenfeldt M, Stapert J, De Jong P, Soeters PB, Wesdorp RIC, Greep JM. TPN catheter sepsis; lack of effect of subcutaneous tunnelling of PVC catheters on sepsis rate. FPEN $\mathcal{Y}$ Parenter Enteral Nutr 1980;5:514-7.

16 Rowley KM, Soni Clubb BS, Smith GJW, Cabin HS. Right sided infective endocarditis as a consequence of flow directed pulmonary artery catheterisation. N Engl F Med 1984;311:1152-6. Ford SE, Manley PN. Indwelling cardiac catheters: an autopsy study of associated endocardial lesions. Arch Pathol Lab Med 1982;106:314-7.

Ducatman BS, McMichan JC, Edwards WD. Catheter induced lesions of the right side of the heart. JAMA 1985;253:791-5.

19 Pace NL, Horton W. Indwelling pulmonary artery catheters. FAMA 1975;233:893-4.

20 Greene JF, Fitzwater JE, Clemmer TP. Septic endocarditis and indwelling pulmonary artery catheters. FAMA 1975;233:891-2.

21 Elliott CG, Zimmerman GA, Clemmer TP. Complications of pulmonary artery catheterisation in the care of critically ill patients: a prospective study. Chest 1979;76:647-52.

22 Yorra FH, Oblath R, Jaffe H, Simmons DH, Levey SE. Massive thrombosis associated with use of the Swan-Ganz catheter. Chest 1974;65:682-4.

23 Connors AF Jr, Castele RJ, Farhat NZ, Tomashefski JF. Complications of right hear catheterisation. Chest 1985;88:567-72.

24 Borow M, Crowley JG. Evaluation of central venous catheter thrombogenicity. Acta Anaesthesio Scand [Suppl] 1985;81:59-64

25 Hoshal VL Jr, Ause RG, Hosk PA. Fibrin sleeve formation on indwelling subclavian central venous catheters. Arch Surg 1971;102:253-8.

26 Chamsi-Pasha $\mathrm{H}$, Irving $\mathrm{MH}$. Right atrial thrombus: a complication of total parenteral nutrition in an adult. BrMed f 1987;295:308.

27 Hoshal VL. The consequences of a cavalier approach to central venous catheterization. Acto Anaesthesiol Scand [Suppl] 1985;81:11-3.

\title{
Selenium and cancer
}

\section{Whether selenium protects against cancer is still unknown}

The relation of selenium with cancer has a long and tortuous history. Early in this century high doses of selenium were briefly advocated for treating haematological malignancies, ${ }^{1}$ but in a study in 1943 high doses of selenium were shown to have induced cirrhosis and hepatocellular tumours in laboratory animals. ${ }^{2}$ Better designed and more extensive studies showed, however, that selenium produced fewer rather than more tumours. Combs and Combs recently summarised 55 studies published since 1949,49 of which found that selenium inhibited cancer. ${ }^{3}$ Yet the question of whether selenium protects against cancer is still wide open.

Selenium is an essential nutrient for $\operatorname{man},{ }^{4}$ and in central China a profoundly low intake causes cardiomyopathy in children. ${ }^{5}$ The plausibility of a link with cancer was increased when selenium was found to be a component of glutathione peroxidase, ${ }^{6}$ which helps protect macromolecules from oxidation stress.

Nearly 20 years ago Shamberger and Frost showed that mortality from cancer in the United States was inversely correlated with selenium concentrations in forage crops. ${ }^{7}$ This finding was refined by Shamberger et al ${ }^{8}$ and others ${ }^{9}$ and extended to international comparisons by Schrauzer et al, who found particularly strong inverse correlations for cancer of the breast and colon by either calculating selenium intake or analysing selenium concentrations in pooled blood specimens ${ }^{10}$ Although these geographical studies support the hypothesis that higher selenium intake reduces the risk of cancer, other dietary and non-dietary factors could account for the associations.

Studies among individuals permit a greater opportunity for controlling potential confounding factors. As selenium in foods varies with concentrations in soil the calculation of intake based on diet will generally provide a poor measure of an individual person's intake: thus most studies have used blood or tissue concentrations. In most case-control studies patients with cancer had lower concentrations of selenium. But studies based on blood concentrations are difficult to interpret; cancer may cause lower concentrations by sequestering selenium, ${ }^{11}$ reducing intake, and altering absorption or secretion. Selenium concentrations decline in patients with cancer as the disease progresses, ${ }^{1213}$ and patients with more advanced disease tend to have lower

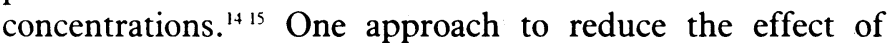
disease on selenium values is to select patients with small or early tumours. Thus Clark et al found reduced plasma selenium concentrations in patients with skin cancers that were not melanomas. ${ }^{16}$

In prospective studies the potential for cancer to alter selenium concentrations is minimised. An efficient design is to collect samples at the outset of the study and later analyse 
selectively only the specimens of those who develop cancer and a sample of those who do not. Using this approach, Willett $e$ al found that mean prediagnostic serum selenium concentrations among ill people who developed cancer were significantly lower than among matched controls. ${ }^{17}$ Those in the lowest quintile of serum selenium concentration had a risk twice as high as those in the highest quintile. In two subsequent prospective studies from Finland, an area low in selenium, a threefold to sixfold increase in the risk of cancer was observed for those with low selenium concentrations. ${ }^{1819}$ Subsequent prospective studies, however, have been less consistent, finding both positive and negative results ${ }^{20-25}(\mathrm{~L}$ Kuller, chemoprevention clinical trials workshop, National Cancer Institute, 1987). Using a technique pioneered by Morris $e t a l{ }^{26}$ Van Noord et al have analysed the selenium concentration in toenails collected from a cohort of premenopausal Dutch women and found no important difference between the few who developed breast cancer and those who did not. ${ }^{27}$

The conflicting findings of the prospective studies have no obvious explanation, but the possibility of a spurious effect because of undiagnosed cancer at the baseline cannot be entirely dismissed. Such an artefact appears to explain the inverse relation between serum retinol concentrations and cancer, which recently generated a flurry of excitement. ${ }^{28}$ Virtamo et al found significantly lower serum selenium concentrations among patients with cancer when the blood was drawn and among those whose cancers were diagnosed within the year..$^{20}$ Most prospective studies have addressed this issue by examining the concentrations among cases at various times after the blood was drawn; in none of the studies with positive findings was there any indication that such a spurious effect was present. This issue can best be resolved with extended follow up of the cohorts that have been studied.

Another possibility for the discrepant results is that studies with negative findings may not have included a sufficient range of selenium concentrations to observe a difference, and the studies with negative results have tended to have a lower variation in selenium concentrations than the studies with positive findings..$^{29}$ Geographical factors are an important determinant of soil (and thus serum) selenium concentrations, and many studies have been conducted within a small area or have matched controls to cases on the basis of geographical location.

Other dietary factors might have confounded the results of some studies. Moreover, possible interactions between nutrients, suggested in some epidemiological studies and well described in animal work, further complicate interpretation of the data. If the effect of selenium does vary according to the concentration of other nutrients-for example, vitamin Ethen discrepant findings might be expected depending on the intake of other dietary factors.

The greatest limitation of existing data is the small number of cases of cancer in any study. For any single investigation the confidence intervals are wide, and nearly all the existing studies are statistically compatible with each other. A $20-30 \%$ reduction in the risk of cancer would be potentially important, and all cancer sites are unlikely to be similarly affected. Much larger studies with adequate variation in selenium concentrations and sufficient numbers of specific cancers would be needed to exclude the possibility of an important beneficial effect of selenium.

Several prospective studies of selenium and cancer are proceeding, including our study of nail specimens collected from nearly 70000 women in 1982 , and should provide substantial new information shortly. Collectively, these investigations may be enough to reject the hypothesis that selenium has an important effect on human cancer. On the other hand, if an inverse relation continues to be seen in an appreciable proportion of studies a randomised trial of supplementation may be justified. For now, however, insufficient evidence exists to recommend that people, other than those living in areas of profound selenium deficiency in central China, supplement their diet with selenium preparations.

W C WILLETT

Professor of Epidemiology and Nutrition, Harvard School of Public Health

M J STAMPFER Assistant Professor of Medicine, Harvard Medical School

Channing Laboratory,

Brigham and Women's Hospital,

Boston,

Massachusetts 02115,

United States

1 Walker $\mathrm{CH}$, Klein E. Selenium-its therapeutic value-especially in cancer. American Medicine 1915:62832.

2 Nelson AA, Fithugh OG, Calvery HO. Liver tumors following cirrhosis caused by selenium in rats. Cancer Res 1943;3:230.

3 Combs GF Jr, Combs SB. The role of selenium in nutrition. Orlando, Florida: Academic Press, 1986:413-61.

4 Food and Nutrition Board, Committee on Dietary Allowances. Selenium. In: Recommended dietary allowances. 9th ed. Washington, DC: National Academy of Sciences, 1980:162-4.

5 Keshan Disease Research Group of the Chinese Academy of Medical Sciences. Epidemiologic studies on the etiologic relationship of selenium and Keshan disease. Chin Med $\mathcal{J}$ 1979;92: 47782.

6 Rotruck JT, Pope AL, Ganther HE, Swanson AB, Hafeman DG, Hoekstra WG. Selenium: biochemical role as a component of glutathione peroxidase. Science 1973;179:588.

7 Shamberger RJ, Frost DV. Possible protective effect of selenium against human cancer. Can Med Assoc J 1969;100:682.

8 Shamberger RJ, Tytko $S A$, Willis $C E$. Antioxidants and cancer part VI. Selenium and age-adjusted human cancer mortality. Arch Environ Health 1976;31:231-5.

9 Cech I, Holguin A, Sokolow H, Smith V. Selenium availability in Texas: possible clinical significance. South Med f 1984;77:1415-20.

10 Schrauzer GN, White DA, Schneider CJ. Cancer mortality correlation studies. III. Statistical associations with dietary selenium intakes. Bioinorganic Chemistry 1977;7:23-34.

11 Rizk SL, Sky-Peck HH. Comparison between concentrations of trace elements in normal and neoplastic human breast tissue. Cancer Res 1984;44:5390-4.

12 Robinson MF, Godfrey PJ, Thomson CD, Rea HM, van Rij AM. Blood selenium and glutathione peroxidase activity in normal subjects and in surgical patients with and without cancer in New Zealand. Am J Clin Nutr 1979;32:1477-85.

13 Sundstrom $\mathrm{H}$, Yrianheikki E, Kauppila A. Serum selenium in patients with ovarian cancer during and after therapy. Carcinogenesis 1984;5:731-4.

14 Shamberger RJ, Rukovena E, Longfield AK, Tytko SA, Deodhar S, Willis CE. Antioxidants and cancer. I. Selenium in the blood of normals and cancer patients. INCI 1973;50:863-70.

15 McConnell KP, Broghamer WL, Blotcky AL, Hurt OJ. Selenium levels in human blood and tissues in health and disease. $\mathcal{J}$ Nutr 1975;105:1026-31.

tissues in health and disease. N Nutr 1975; 105:1026-31.
16 Clark LC, Graham GF, Crounse KG, Grimson R, Hulka B, Shy CM. Plasma selenium and skin neoplasms: a case control study. Nutr Cancer 1984;6:13-21.
.

17 Willett WC, Polk BF, Morris JS. Prediagnostic serum selenium and risk of cancer. Lancel 1983;ii: 130-4.

18 Salonen JT, Alfthan G, Huttunen JK, Puska P. Association between serum selenium and the risk of cancer. Am F Epidemiol 1984;120:342-9.

19 Salonen JT, Salonen R, Lappetlainen R, Meaenpaa PH, Alfthan G, Puska P. Risk of cancer in relation to serum concentrations of selenium and vitamins $A$ and $E$ : matched case-control analysis of prospective data. $\mathrm{Br}$ Med $\mathcal{J}$ 1985;290:417-20.

20 Virtamo J, Valkeila E, Alfthan G, Punsar S, Huttunen J, Karvonen MJ. Serum selenium and risk of cancer. A prospective follow-up of nine years. Cancer 1987;60:145-8.

21 Peleg I, Morris S, Hames CG. Is serum selenium a risk factor for cancer? Med Oncol Tumor Pharmacother 1985;2:157-63.

22 Menkes M, Comstock G, Vuilleumier JP, Helsing KJ, Rider AA, Brookmeyer R. Serum betacarotene, vitamins A and E, selenium, and the risk of lung cancer. $N$ Engl J Med 1986;315: $1250-4$.

23 Kok FJ, de Bruijn AM, Hofman A, Vermeermen R, Valkenburg HA. Is serum selenium a risk factor for cancer in men only? Am $\mathcal{J}$ Epidemiol 1987;125:12-6.

24 Nomura A, Heilbrun LK, Morris JS, Stemmermann N. Serum selenium and risk of cancer by specific sites: case-control analysis of prospective data. JNCI 1988 (in press).
s.

$25 \mathrm{Fex} \mathrm{G}$, Pettersson B, Akesson B. Low plasma selenium as a risk for cancer death in middle-aged men. Nutr Cancer 1987;10:221-9.

26 Morris JS, Stampfer MJ, Willett WC. Dietary selenium in humans: toenails as an indicator. Biological Trace Element Research 1983;5:529-37.

27 Van Noord PAH, Collette HJA, Maas MJ, De Waard F. Selenium levels in nails of premenopausal breast cancer patients assessed prediagnostically in a cohort-nested case-referent study among women screened in the DOM project. Int $\mathcal{A}$ Epidemiol 1987;16:318-22.

28 Wald N, Boreham J. Serum retinol and subsequent risk of cancer. Br $\mathcal{X}$ Cancer 1986;54:957-61.

29 Stampfer MJ, Colditz GA, Willett WC. The epidemiology of selenium and cancer. In: Franks LM, Wigley CB, Wyke JA, eds. Cancer surveys. Oxford: Oxford University Press, 1988 (in press). (Kinlen L, ed. Diet and cancer.) 